\title{
Specific humoral immunity in Osteichthyes
}

\author{
MICHAE P. STOSIK ${ }^{1}$, BEATA TOKARZ-DEPTU $A^{2}$, WIESŁAW DEPTUŁA ${ }^{3}$ \\ 'Department of Microbiology and Genetics, Faculty of Biological Sciences, University of Zielona Gora, Zielona Gora, Poland \\ ${ }^{2}$ Department of Immunology, Faculty of Biology, University of Szczecin, Szczecin, Poland \\ ${ }^{3}$ Department of Microbiology, Faculty of Biology, University of Szczecin, Szczecin, Poland
}

\begin{abstract}
The fish immune system is extremely complex and has considerable adaptive potential. In Osteichthyes, the system is formed by lymphopoietic organs which are important for the differentiation and maturation of the immune system cells. These organs include the anterior kidney (phronephros), the thymus, the spleen, the posterior kidney (mesonephros), and mucosa-associated lymphoid tissues (MALT). Apart from the lymphocytic organs and the MALT system, the immune system components include defensive cells and their products. Those identified in fish include, inter alia, monocytes/macrophages, melanomacrophages, neutrophilic granulocytes, thrombocytes, B cells, plasma cells, and T cells. The roles of the individual components of the organisation of the immune system, the organs, and lymphoid tissue as well as the constituents conditioning the innate and adaptive immunity mechanisms are considered equally important, especially in the context of functional interdependence. The progress in the exploration of the processes of specific humoral immunity in Osteichthyes and the possibilities of their practical application is increasingly promising in view of the expected need for protection of fish against diseases.

The paper discusses selected issues concerning recent knowledge about haematopoiesis of B cells, plasmablasts, plasma cells, and immunoglobulins (IgM, IgD, IgT/IgZ).
\end{abstract}

Key words: Osteichthyes, haematopoiesis, B lymphocytes, plasmablasts, plasmacytes, immunoglobulins.

(Centr Eur J Immunol 2018; 43 (3): 335-340)

\section{Introduction}

The fish immune system is extremely complex and has considerable adaptive potential. In Osteichthyes, the system is formed by lymphopoietic organs which are important for the differentiation and maturation of the immune system cells. These organs include the anterior kidney (phronephros), the thymus, the spleen, the posterior kidney (mesonephros), and mucosa-associated lymphoid tissues (MALT) including gut-associated lymphoid tissue (GALT), skin-associated lymphoid tissue (SALT), gill-associated lymphoid tissue (GIALT), and nasopharynx-associated lymphoid tissue (NALT) [1]. MALT also includes lymphoid tissue clusters which have been identified in gills of salmon (Salmo salar) and described in recent years. Such clusters are referred to as ILT (interbranchial lymphoid tissue). As opposed to the other types of mucosa-associated lymphoid tissue that take the scattered form, ILT is organised tissue [2, 3]. Apart from the lymphocytic organs and the MALT system, the immune system components include defensive cells and their products. Those identified in fish include, inter alia, monocytes/macrophages, melanomacrophages, neutrophilic granulocytes, thrombocytes, B cells, plasma cells, and T cells [4-9].
The need to have necessary expertise on all the factors determining the development of the innate and adaptive immune response in Osteichthyes remains insatiable. The problem seems especially important, in particular from epidemiological and economic points of view, from the angle of the constantly high health risks to wild and farmed fish that are created by more or less severe environmental stressors as well as by genetic fingerprinting of pathogenic microorganisms that changes in fish habitats. Attempts to eliminate those risks and to counteract the often abrupt changes in the living conditions of fish in their natural and farmed environments generate wide-ranging and deep adaptation processes in these animals. The adaptation processes involve a number of physiological processes, including changes in the reactivity of the innate and adaptive immunity mechanisms $[10,11]$.

This paper presents selected aspects of specific humoral immunity in Osteichthyes, i.e. issues concerning haematopoiesis, B cells, plasmablasts, plasma cells, and immunoglobulins.

\section{Haematopoiesis, B cells, plasmablasts, and plasma cells}

In Osteichthyes, the role of a haematopoietic organ/ tissue is played by the anterior kidney (phronephros, an

Correspondence: Prof. Michał P. Stosik, Department of Microbiology and Genetics, Faculty of Biological Sciences, University of Zielona Gora, Prof. Z. Szafrana 1 St., 65-516 Zielona Gora, Poland, e-mail: m.stosik@wnb.uz.zgora.pl Submitted: 7.11.2017; Accepted: 12.12.2017 
analogue of the K1 kidney segment in fish of the genus Oncorhynchus, where the kidney is divided into five segments, K1 to K5), deprived of nephrons and thus of the filtration and excretory functions that are fulfilled by the other kidney segments, including the posterior kidney $m e$ sonephros, an analogue of K5 [12, 13]. All haematopoietic differentiation pathways, i.e. erythropoiesis, myelopoiesis, and lymphopoiesis, have been identified in these fish [11, $12,14]$. The highest concentration of developmental forms of B cells conditioning specific humoral immunity is observed in the anterior kidney. In that kidney segment there are proliferating B cell precursors as wells as plasmablasts and plasma cells that are classified as synthesising and antibody-secreting cells (ASC) [12, 15-17]. It is assumed [18] that the "haematopoietic" borderline between B cells and the cells of myeloid origin in fish is not very clear, and the cells of both origins demonstrate high functional flexibility. This is documented in lower vertebrates, including Osteichthyes, by the occurrence of a transitional stage in the evolution of B lymphocytes. In that stage, the cells that condition the innate/non-specific immunity mechanisms and are capable of phagocytosis evolve towards specialised forms, which are important for the development of specific immune response in higher vertebrates. This is expressed in, inter alia, the properties of IgM cells identified in fish, the properties of $\operatorname{IgM}^{-}$cells present in the anterior kidney, and in peripheral blood (with a strongly marked ability to phagocytise) and of membrane (mIgM) and secretory (sIgM) cells (with a poorer ability to phagocytise). Kidneys in Osteichthyes are considered to be highly heterogeneous organs [18]. Apart from fulfilling the haematopoietic function, the anterior kidney also plays the role of an endocrine gland - the adrenal gland because it contains intrarenal adrenal cells, clusters of corticosteroid cells secreting the adrenocorticotropic hormone (ACTH) and cortisol as well as chromaffin cells secreting catecholamines [11, $19,20]$. In the posterior kidney, which, as opposed to the anterior kidney, fulfils filtration and excretory functions, there are in turn cells of the immune system, i.e. activated B cells, plasmablasts, and plasma cells. However, kidneys of Osteichthyes contain separate, location-dependent (K1K5) phenotype patterns of B cells [12].

The common lymphocyte progenitor (CLP) is the earliest developmental stage of cells of lymphoid origin, including B cells. Their further development/differentiation stages include the pro-B stage and the pre-B stage (in sequence, large and small pre-B cells) as well as immature and mature B cells $[12,13]$. Mature B cells migrate from the anterior kidney to the posterior kidney, as well as to the spleen and into the bloodstream. In the posterior kidneys and the spleens, the cells are subject to activation by, inter alia, melanomacrophages classified into antigen-presenting cells (APC) [21] and by T lymphocytes. This leads in the next differentiation stages to the formation of plasmablasts as wells as of short-lived and long-lived plasma cells [12,
15]. As can be seen [12, 15, 22], short-lived plasma cells stay in the spleen, whereas long-lived cells migrate to the anterior kidney. This is the main area where mature plasma cells (MPC) with the Pax5 $5^{-}$phenotype $\operatorname{IgM}^{-}$spread [23, 24]. Studies also show that both the spleen and the posterior kidney are peripheral/secondary lymphoid organs where antigen presentation takes place and where immune response develops, whereas the anterior kidney is a central/ main lymphoid organ where B cells form and mature [12, $13,16,23]$. Analysis of B cells by flow cytometry method confirms the fact that they are identifiable, in the particular developmental stages, based on a combined expression of specific transcription factors that play an important role in the development of B cells in vertebrates (inter alia: Ikaros, E2A, EBF1, Pax5, Blimp1, Xbp1) and class M, membrane and secretory immunoglobulins (IgM, mIgM, and sIgM, respectively) in different stages of immunity dependent on $\mathrm{B}$ cells [13, 16, 25-28]. There is evidence that $\mathrm{B}$ cells differ in the functions and demonstrate different properties, which are conditioned by, inter alia, the activity of transcription factors [23]. An early stage of the $\mathrm{B}$ cell development may be characterised by co-expression of the transcription factor EBF1 (early B-cell factor) and of the RAG1 gene (recombination activation gene) that is responsible for the activation of gene rearrangement for immunoglobulin receptor components, V-D-J, which code the B-cell receptor complex (BCR complex) recognising an antigen [13, 16]. MacMurray et al. [29] have reported of the factor EBF1 being expressed even at CLP and at a higher expression level, in large pre-B cells. In B cells in the subsequent developmental stages (small pre-B cells, immature, and mature B cells), the picture of combined expression of transcription factors manifests itself in a low level of expression of the factor EBF1 and in the absence of the factor RAG1 with simultaneous strong expression of the factor Pax5.PD (an isoform of the Pax5 gene belonging to the Pax transcription factor family), which is the most important factor in the differentiation of B cells and the presence of $\mathrm{mIgM}[11,29]$. The transcription factor Pax5 and $\mathrm{mIgM}$ are also present in plasmablasts [24]. In contrast, the ultimately shaped plasma cells are characterised by the absence of the transformation factor Pax 5 and of mIgM, with a simultaneous high level of IgM's ability to secrete [23]. It is also useful to highlight the fact that the presence of Pax5.PD ${ }^{+} \mathrm{B}$ cells is very common and conservative in Osteichthyes. About $25 \%$ of the anterior kidney white blood cells (WBC) in different species of Osteichthyes, e.g. in rainbow trout (Oncorhynchus mykiss) [16], sockeye salmon (Oncorhynchus nerka) [30], or in common carp (Cyprinus carpio) [31] are Pax5.PD ${ }^{+}$cells. Furthermore, a small part of the B-cell population is distinguished by expression of $\operatorname{IgT}$ and/or IgZ (in terms of functions, IgT/Z correspond to $\operatorname{Ig} \mathrm{A}$ in mammals, also as a component of mucosal defence) or to $\operatorname{IgD}[11,23,32,33]$. According to Li et al. [18], the anterior kidney and the peripheral blood 
in rainbow trout (Oncorhynchus mykiss) contain $\operatorname{IgM}^{+}$ $\mathrm{B}$ cells with a phenotype profile defined by the expression of genes coding $\mathrm{SIgM}$ as well as $\mathrm{mIgM}$ and $\mathrm{mIgD}$. Those studies also show that the expression of $\mathrm{mIgD}$ genes was significantly higher in $\operatorname{IgM}^{+}$cells demonstrating the ability to phagocytise. In that case, there were also $\operatorname{IgM}^{-} \operatorname{IgT}^{+}$cells that did not phagocytise. Their profile of expressed genes included mIgT, sIgT, TCR $\alpha$ (T-cell receptor- $\alpha)$, TCR $\beta$ (T-cell receptor- $\beta$ ), $\mathrm{CD} 8 \alpha$ (cluster of differentiation $8-\alpha$ ), and CSF-1R (colony stimulating factor 1 receptor), which probably, as suggested by Li et al. [18], make up a separate subgroup of lymphocytes, the properties of which correspond to those of $\mathrm{IgM}^{-}$cells of lymphoid origin. There are equally large numbers of mature $\mathrm{B} \mathrm{Pax} 5 . \mathrm{PD}^{+}, \mathrm{Xbp}^{+}$, and IgM cells in the spleen where the cells are activated by an antigen [12, 16, 24, 30]. After the antigen activation, there are also plasmablasts as well as short-lived and longlived plasma cells as the ones that are concomitant with B Pax5.PD ${ }^{+} \mathrm{Xbp}^{+}$cells and IgM-secreting cells [15, 22]. It is assumed that the activated $\mathrm{B}$ cells, $\mathrm{Pax} 5^{+} \mathrm{IgM}{ }^{+}$begin to synthesise and secrete small amounts of $\operatorname{IgM}$, and this ability is enhanced in the subsequent differentiated forms of $\mathrm{B}$ cells, i.e. the proliferating $\operatorname{IgM}^{+}$plasmablasts, and later in plasma cells, non-proliferating $\operatorname{IgM}^{-} \mathrm{Pax}^{-}[12,15$, $17,21,22]$. Mature $\operatorname{IgM}^{+} \mathrm{B}$ cells sensitive to LPS are also present in fish blood [13].

In Osteichthyes, just as in Chondrichthyes and mammals, the specific immunity mechanisms are marked by the presence of crucial molecules such as BCR (B-cell receptor), secretory immunoglobulins, TCR (T-cell receptor, $\mathrm{CD}^{+}$and $\mathrm{CD}^{+}$), AID (activation-induced cytidine deaminase), cytokines, or major histocompatibility complex (MHC) class I and II antigens [1, 9, 34-37]. Immunoglobulins are the most important components of specific humoral immunity. To date, different heavy chain isotypes (IgH), including IgM, IgD/IgW, IgG, IgA, IgE, IgY, IgX, $\mathrm{IgZ/IgT,} \mathrm{IgF}$, and $\mathrm{IgO}$ have been identified in different vertebrate species [38]. For Osteichthyes, three isotypes, $\operatorname{IgH}, \mu, \delta$, and $\tau / \zeta$, have been described. In this systematic group, these types form a basis for the division of immunoglobulins into three classes: $\operatorname{IgM}, \operatorname{IgD}$, and $\operatorname{IgT/} \operatorname{IgZ}$. The $\mathrm{H} \tau / \zeta$ chain (H $\tau$-IgT was first identified in rainbow trout, Oncorhynchus mykiss, whereas $\mathrm{H} \zeta$-IgZ was first identified in zebrafish, Danio rerio) $[17,36,39]$. In Osteichthyes, these immunoglobulins are present in the plasma, skin, intestines, gills, and in the bile as well [40]. However, it must be taken into account that the presence of all the antibody classes named above has not been demonstrated in all $O S_{-}$ teichthyes species [35]. The primary contact of Osteichthyes with an antigen generates in them, just as in species of higher systematic levels, synthesis and release of specific antibodies at a certain level, which is however lower than that in the case of secondary response developing as a result of new contact with an antigen. The secondary im- mune response evolves more quickly and more intensely, with a higher titre of specific antibodies [40].

\section{Immunoglobulins}

$\operatorname{IgM}$ is the first immunoglobulin identified in fish [41]. In B cells, it is in the form of a surface immunoglobulin (mIg), while in the serum and mucous membranes it is in the form of a secretory immunoglobulin ( $\mathrm{SIg}$ ). $\mathrm{sIgM}$ is a tetrameric molecule built of four monomeric units, each of which is built of two heavy chains $(\mathrm{H})$ and two light chains (L). The $\mathrm{H}$ chain is composed of four domains, $\mathrm{C}_{\mathrm{H}} \mu 1-4$, whereas $\mathrm{mIgM}$ has a monomeric form and is shorter than sIg as a result of alternative splicing. It is characterised by the absence of the domain $\mathrm{C}_{\mathrm{H}} \mu 4[17,35,42]$. Even though serum $\operatorname{IgM}$ has been demonstrated to have a tetrameric form in most Osteichthyes, serum IgM has also been described to have a monomeric form. This form was found in Epinephelus itaira (family: Serranidae, genus: Epinephelus) and in Archosargus probatocephalus (family: Sparidae, genus: Archosargus) [42]. The quantity of IgM as natural antibodies in fish serum ranges between 800 and $9000 \mu \mathrm{g} / \mathrm{ml}$. Their presence as specific antibodies developing in response to the presented antigen is observed even prior to immunisation [17, 35, 43-45]. These antibodies are also found in mucous membranes [1, 33, 45]. Just as in higher vertebrates, $\operatorname{sgM}$ in fish can be transported to the mucosal surface after they have formed a complex with the receptor for polymeric forms of immunoglobulins, pIgR (polymeric Ig receptor). What needs to be highlighted is the fact that, as opposed to mammals in which a joining chain $(\mathrm{J})$ is used for transporting $\operatorname{IgM}$ via $\mathrm{pIgR}$, the role of the $\mathrm{J}$ chain in fish is probably played (as no $\mathrm{J}$-chain is present in the IgM structure) by an H chain that presumably has a binding module for pIgR. Within the mucous membrane, IgM are also locally produced by plasma cells in response to an antigen [17]. Studies have shown [17] that just as in higher vertebrates, IgM fulfil essential effector defence functions in areas covered by both innate and adaptive immunity mechanisms. It has been demonstrated that IgM takes part in the killing of bacterial infectious agents, Aeromonas salmonicida, and the neutralisation of IHN viruses (infectious haematopoietic necrosis) and VHS viruses (viral haemorrhagic septicaemia) as well as of parasites, Cryptobia salmositica [17]. The contribution of IgM to the activation of the complement, the opsonisation of bacterial antigens, inter alia Francisella asiatica and Photobacterium damsela prior to the phagocytosis of these microorganisms by macrophages, have also been proven [35, 43, 46, 47].

$\mathrm{IgD}$ is identified in all vertebrates except for birds, and it is possible that $\operatorname{IgD}$ is equivalent to $\operatorname{IgM}$ in terms of phylogenesis $[42,48]$. In Osteichthyes, $\operatorname{IgD}$ occurs in peripheral blood in the form of both $\mathrm{mIg}$ (in channel catfish - Ictalurus punctatus, B cells make up some $80 \%$, 
whereas $\operatorname{IgM}{ }^{+} / \mathrm{IgD}^{+}$account for the remaining percentage) and sIg, in a concentration incomparably lower than IgM (in rainbow trout - Oncorhynchus mykiss - between 2 and $80 \mu \mathrm{g} / \mathrm{ml})[32,49]$. There is evidence of sIgD in the anterior and posterior kidneys, the spleen, and the gills [35]. Also, Edholm et al. [49] claim, based on their research on channel catfish (Ictalurus punctatus), that $\operatorname{IgD}$ is in the character of an antigen-binding receptor both in the case of $\mathrm{IgM}^{+} / \mathrm{IgD}^{+}$cells with a high level of $\operatorname{IgM}$ and a low level of $\operatorname{IgD}$ in peripheral blood and in the case of $\mathrm{IgM}^{-} /$ $\mathrm{IgD}^{+}$, with a high level of IgD and the absence of IgM. It has been demonstrated that, just as in mammals, plasma cells of this immunoglobulin are present in gut-associated lymphoid tissue (GALT) and in the gills (GIALT). Additionally, there were very small numbers of plasma cells in peripheral blood (ca. 3\%) [17, 32]. The significant role of this antibody isotype in the development of specific immune response in mucosa-associated lymphoid tissue is indicated by the presence of the $\mathrm{V}$ domain in the $\operatorname{sgD}$ structure [32]. As studies on rainbow trout (Oncorhynchus mykiss) demonstrate, the sIgD level rises in GALT and GIALT in response to the immunisation with an attenuated strain of Flavobacterium psychrophilum [45]. The results of those studies confirm, as stated by Makesh et al. [45], the essential or simply specialised role of $\operatorname{sIgD}$ in mucosal immunity. The unique property of $\mathrm{IgD}$ is an $\mathrm{H}$ chain in the form of a hybrid created from the $\mathrm{C} \mu 1$ domain that is present in the $\operatorname{IgD}$ structure in all fish species, and from the $\mathrm{C} \delta$ domain that occurs in various numbers (from seven to as many as $16 \mathrm{C} \delta$ domains) in different fish species [32, $35,39,50,51]$. In fish, an IgD H chain contains segments corresponding, one by one, to VDJ genes that codes the variable parts, in the fixed part, $\mathrm{C} \mu 1$ linked to a variable number of the $\mathrm{C} \delta$ domains, depending on fish species and the transmembrane part. IgD molecules in fish lack a hinge region [42].

IgT/IgZ is the Ig class that has been most recently found in such species of Osteichthyes as zebrafish (Danio rerio) [50, 52], rainbow trout (Oncorhynchus mykiss) [53, 54], Atlantic salmon (Salmo salar) [55], three-spined stickleback (Gasterosteus aculeatus) [56], and common carp (Cyprinus carpio) [57], in which the genome order, structure, and biochemical properties of these proteins have been identified. Research on rainbow trout (Oncorhynchus mykiss) has shown that IgT take part in the development of an immune reaction in response to bacterial and viral infections, and to DNA inoculations. These immunoglobulins also play an important role in the protection of the gills (GIALT), the skin (SALT), and of the gut mucosa (GALT) $[45,54,58,59]$. The structure of the domains $\mathrm{C}_{\mathrm{H}} \tau / \zeta$ varies in different fish species. In rainbow trout and zebrafish, IgT/IgZ have four domains, $\mathrm{C}_{\mathrm{H}} \tau 1-4$ and $\mathrm{C}_{\mathrm{H}} \zeta 1-4$, respectively, whereas in tiger puffer (Takifugu rubripes; synonym: Fugu rubripes) they only have two domains, $\mathrm{C}_{\mathrm{H}} \zeta$ which correspond to $\mathrm{C}_{\mathrm{H}} \zeta 1$ and $\mathrm{C}_{\mathrm{H}} \zeta 4$, respectively, in zebrafish. In three-spined stickleback, they have three $\tau$ domains and no $\mathrm{C}_{\mathrm{H}} 2$ domain among those identified in rainbow trout. Whereas in common carp, besides a subclass of IgZ1, there is a subclass of IgZ2 and chimeric $\operatorname{IgM-IgT}$ where the $\mathrm{H}$ chain is built of two domains, i.e. $\mathrm{C}_{\mathrm{H}} \mu$ and $\mathrm{C}_{\mathrm{H}} \zeta$ (similar to $\mathrm{C}_{\mathrm{H}} \zeta 4$ in rainbow trout) $[17,35,57$, $60]$. Moreover, three subclasses of $\operatorname{IgT}$, namely $\operatorname{IgT} 1(\tau 1)$, $\operatorname{IgT2}(\tau 2)$, and $\operatorname{IgT} 3(\tau 3)$ [54], have been identified in rainbow trout serum based on an analysis of $\mathrm{CH}$ domains using the LC-MS/MS technique (liquid chromatography-tandem mass spectrometry). The picture reflecting the immune reactivity related to IgT/Z is not always homogenous and thus not unambiguous. Studies carried out on rainbow trout during a parasitic invasion in its guts have demonstrated, for example, an increase in the number of $\operatorname{IgT}^{+} \mathrm{B}$ cells with an unchanged number of $\operatorname{IgM}^{+} \mathrm{B}$ cells and a concomitant similar picture of the changes in the Ig levels in the gut mucosa and an increase in the quantity of IgT with no changes in the quantity of $\operatorname{IgM}$. Furthermore, the IgT concentration in the gut mucosa $7.1 \mu \mathrm{g} / \mathrm{ml}$ ) was twice as high as the level of these Ig in serum [59]. IgT B cells in rainbow trout account for between 16 and $28 \%$ of the total number of these cells identified in the peripheral blood, the spleen, the anterior kidney, and in the body cavity, whereby the presence of $\operatorname{IgM}^{+} \mathrm{B}$ cells absolutely dominates. The percentage shares of both the cell types in gut-associated lymphoid tissue (GALT) are completely different, shaped with values $54.3 \% \mathrm{IgT}^{+}$and $46.7 \% \mathrm{IgM}^{+}$, respectively. $\mathrm{IgT} / \mathrm{Z}$ is considered the most important among Ig within mucosa-associated lymphoid tissue $[17,54,59]$. Studies show that IgT in rainbow trout serum has a monomeric form (IgM has a polymeric form), whereas in the gut mucus, it is in a polymeric (tetrameric) form, just as IgM, and the transport of IgT from the serum to the gut mucosa can take place with the participation of the receptor for polymeric forms of immunoglobulins (pIgR) [59]. Similar results have been obtained by the team of Xu et al. [58] for rainbow trout affected by an invasion of freshwater ich (Ichthyophthirius multifiliis). These fish were studied for, inter alia, the presence of $\operatorname{IgT}^{+} \mathrm{B}$ cells and of polymeric IgT in skin-associated lymphoid tissue (SALT).

\section{Conclusions}

The exploration of the issues addressed in this paper should be judged as very dynamic and advanced in terms of methods and techniques. The progress in the exploration of the specific humoral immunity mechanisms in Osteichthyes and the possibilities of their practical use is increasingly promising in view of the expected need for protection of fish against diseases. The observed picture of specific humoral immunity in Osteichthyes is very complex and seems to be a combination of immune elements with high adaptive potential and an ability to protect the body of these animals. 
The authors declare no conflict of interest.

\section{References}

1. Salinas I (2015): The Mucosal Immune System of Teleost Fish. Biology 4: 525-539.

2. Haugarvoll E, Bjerkas I, Nowak BF, et al. (2008): Identification and characterization of a novel intraepithelial lymphoid tissue in the gills of Atlantic salmon. J Anat 213: 202-209.

3. Aas IB, Austbř L, König M, et al. (2014): Transcriptional characterization of the $\mathrm{T}$ cell population within the salmonid interbranchial lymphoid tissue. J Immunol 193: 3463-3469.

4. Stosik M (1995): Kształtowanie się wybranych parametrów immunologicznych i hematologicznych u karpi (Cyprinus carpio L.) hodowlanych zdrowych i chorych w czasie ich rozwoju osobniczego. Wydawnictwo Naukowe Uniwersytetu Szczecińskiego, Szczecin.

5. Zapata A, Amemiya CT (2000): Phylogeny of lower vertebrates and their immunological structures. Curr Top Microbiol Immunol 248: 67-107.

6. Stosik M, Deptuła W (2001): Immunologia ryb. Wydawnictwo Naukowe Uniwersytetu Szczecińskiego, Szczecin.

7. Rombout JH, Huttenhuis HB, Picchietti S, Scapigliati G (2005): Phylogeny and ontogeny of fish leucocytes. Fish Shellfish Immunol 19: 441-455.

8. Sunyer JO (2012): Evolutionary and Functional Relationships of B Cells from Fish and Mammals: Insights into their Novel Roles in Phagocytosis and Presentation of Particulate Antigen. Infect Disord Drug Targets 12: 200-212.

9. Sunyer JO (2013): Fishing for mammalian paradigms in the teleost immune system. Nat Immunol 14: 320-326.

10. Makrinos DL, Bowden TJ (2016): Natural environmental impacts on teleost immune function. Fish Shellfish Immunol 53: 50-57.

11. Zwollo P (2018): The humoral immune system of anadromous fish. Dev Comp Immunol 80: 24-33.

12. Zwollo P, Cole S, Bromage E, Kaattari S (2005): B cell heterogeneity in the teleost kidney: evidence for a maturation gradient from anterior to posterior kidney. J Immunol 174: 6608-6616.

13. Zwollo P (2011): Dissecting teleost B cell differentiation using transcription factors. Dev Comp Immunol 35: 898-905.

14. Kobayashi I, Katakura F, Moritomo T (2016): Isolation and characterization of hematopoietic stem cells in teleost fish. Dev Comp Immunol 58: 86-94.

15. Bromage ES, Kaattari IM, Zwollo P, Kaattari S L (2004): Plasmablast and plasma cell production and distribution in trout immune tissues. J Immunol 173: 7317-7323.

16. Zwollo P, Haines A, Rosato P, Gumulak-Smith J (2008): Molecular and cellular analysis of $\mathrm{B}$ cell populations in the rainbow trout using Pax5 and immunoglobulin markers. Dev Comp Immunol 32: 1482-1496.

17. Ye J, Kaattari IM, Ma C, Kaattari S (2013): The teleost humoral immune response. Fish Shellfish Immunol 35: 17191728.

18. Li J, Barreda DR, Zhang YA, et al. (2006): B lymphocytes from early vertebrates have potent phagocytic and microbicidal abilities. Nat Immunol 7: 1116-1124.

19. Wojtaszek J, Dziewulska-Szwajkowska D, Łozińska-Gabska M, et al. (2002): Hematological Effects of High Dose of Cortisol on the Carp (Cyprinus carpio L.): Cortisol Effect on the Carp Blood. Gen Comp Endocrinol 125: 176-183.
20. Castillo J, Teles M, Mackenzie S, Tort L (2009): Stress-related hormones modulate cytokine expression in the head kidney of gilthead seabream (Sparus aurata). Fish Shellfish Immunol 27: 493-499.

21. Saunders HL, Oko AL, Scott AN, et al. (2010): The cellular context of AID expressing cells in fish lymphoid tissues. Dev Comp Immunol 34: 669-676.

22. Ye J, Kaattari I, Kaattari S (2011): Plasmablasts and plasma cells: reconsidering the organization of the teleost immune response. Dev Comp Immunol 35: 1273-1281.

23. Zwollo P, Mott K, Barr M (2010): Comparative analyses of $\mathrm{B}$ cell populations in trout kidney and mouse bone marrow: establishing "B cell signatures". Dev Comp Immunol 34: 1291-1299.

24. Barr M, Mott K, Zwollo P (2011): Defining terminally differentiating $\mathrm{B}$ cell populations in rainbow trout immune tissues using the transcription factor XbpI. Fish Shellfish Immunol 31: 727-735.

25. Hansen JD, Strassburger P, Du Pasquier L (1997): Conservation of a master hematopoietic switch gene during vertebrate evolution: isolation and characterization of Ikaros from teleost and amphibian species. Eur J Immunol 27: 3049-3058.

26. Hikima J, Lennard M, Wilson M, et al. (2005): Evolution of vertebrate $\mathrm{E}$ protein transcription factors: comparative analysis of the E-protein gene family in Takifugu rubripes and humans. Physiol Genomics 21: 144-151.

27. Hikima J, Middleton D, Wislon MR, et al. (2005): Regulation of immunoglobulin gene transcription in teleost fish: identification, expression, and functional properties of E2A in channel catfish. Immunogenetics 57: 273-282.

28. Ohtani M, Miyadai T, Hiroishi S (2006): B-lymphocyte-induced maturation protein-1 (Blimp-1) gene of torafugu (Takifugu rubripes). Fish Shellfish Immunol 20: 409-413.

29. MacMurray E, Barr M, Bruce A, et al. (2013): Alternative splicing of the trout Pax5 gene and identification of novel $\mathrm{B}$ cell populations using Pax5 signatures. Dev Comp Immunol 41: 270-281.

30. Schouten J, Clister T, Bruce A, et al. (2013): Sockeye salmon retain immunoglobulin-secreting plasma cells throughout their spawning journey and post-spawning. Dev Comp Immunol 40: 202-209.

31. Piazzon MC, Savelkoul HSJ, Pietretti D, et al. (2015): Carp Il10 has anti-inflammatory activities on phagocytes, promotes proliferation of memory $\mathrm{T}$ cells, and regulates $\mathrm{B}$ cell differentiation and antibody secretion. J Immunol Balt 194: 187-199.

32. Ramirez-Gomez F, Greene W, Rego K, et al. (2012): Discovery and characterization of secretory $\operatorname{IgD}$ in rainbow trout: secretory $\mathrm{IgD}$ is produced through a novel splicing mechanism. J Immunol 188: 1341-1349.

33. Salinas I, Zhang YA, Sunyer JO (2011): Mucosal immunoglobulins and B cells of teleost fish. Dev Comp Immunol 35: 1346-1365.

34. Uribe C, Folch H, Enriquez R, Moran G (2011): Innate and adaptive immunity in teleost fish: a review. Vet Med (Praha) 56: 486-503.

35. Mashoof S, Criscitiello MF (2016): Fish Immunoglobulins. Biology 5: 45.

36. Wang T, Secombes CJ (2013): The cytokine networks of adaptive immunity in fish. Fish Shellfish Immunol 35: 17031718.

37. Wan F, Hu C, Ma J, et al. (2017): Characterization of $\gamma \delta$ Tcells from Zebrafish provides insights into their important role in adaptative humoral immunity. Front Immunol 7: 675. 
38. Sun Y, Wei Z, Hammarstrom L, Zhao Y (2011): The immunoglobulin gene in jawed vertebrates: A comparative overview. Dev Comp Immunol 35: 975-981.

39. Fillatreau S, Six A, Magadan S, et al. (2013): The astonishing diversity of Ig classes and B cell repertoires in teleost fish. Front Immun 4: 28.

40. Morrison RN, Nowak BF (2002): The antibody response of teleost fish. Semin. Avian Exot Pet Med 11: 46-54.

41. Olesen NJ, Jorgensen PEV (1986): Quantification of serum immunoglobulin in rainbow trout Salmo gairdneri under various environmental conditions. Dis Aquat Org 1: 183-189.

42. Edholm ES, Bengten E, Wilson M (2011): Insights into the function of IgD. Dev Comp Immunol 35: 1309-1316.

43. Boes M (2000): Role of natural and immune IgM antibodies in immune responses. Mol Immunol 37: 1141-1149.

44. Whyte SK (2007): The innate immune response of finfish e A review of current knowledge. Fish Shellfish Immunol 23: 1127-1151.

45. Makesh M, Sudheesh PS, Caina KD (2015): Systemic and mucosal immune response of rainbow trout to immunization with an attenuated Flavobacterium psychrophilum vaccine strain by different routes. Fish Shellfish Immunol 44: 156163.

46. Boshra H, Gelman AE, Sunyer JO (2004): Structural and functional characterization of complement $\mathrm{C} 4$ and $\mathrm{C} 1$ s-like molecules in teleost fish: insights into the evolution of classical and alternative pathways. J Immunol 173: 349-359.

47. Cooper NR (1985): The classical complement pathway: activation and regulation of the first complement component. Adv Immunol 37: 151-216.

48. Ohta Y, Flajnik M (2006): IgD, like IgM, is a primordial immunoglobulin class perpetuated in most jawed vertebrates. Proc Natl Acad Sci U S A 103: 10723-10728.

49. Edholm ES, Bengten E, Stafford JL, et al. (2010): Identification of two IgD+ B cell populations in channel catfish, Ictalurus punctatus. J Immunol 185: 4082-4094.

50. Danilova N, Bussmann J, Jekosch K, Steiner LA (2005): The immunoglobulin heavy-chain locus in zebrafish: identification and expression of a previously unknown isotype, immunoglobulin Z. Nat Immunol 6: 295-302.

51. Stenvik J, Jřrgensen TO (2000): Immunoglobulin D (IgD) of Atlantic cod has a unique structure. Immunogenetics 51: 452-461.

52. Hu YL, Xiang LX, Shao JZ (2010): dentification and characterization of a novel immunoglobulin $\mathrm{Z}$ isotype in zebrafish: Implications for a distinct B cell receptor in lower vertebrates. Mol Immunol 47: 738-746.

53. Hansen JD, Landis ED, Phillips RB (2005): Discovery of a unique Ig heavy-chain isotype (IgT) in rainbow trout: implications for a distinctive B cell developmental pathway in teleost fish. Proc Natl Acad Sci U S A 102: 6919-6924.

54. Zhang N, Zhang XJ, Chen DD, et al. (2017): Molecular characterization and expression analysis of three subclasses of IgT in rainbow trout (Oncorhynchus mykiss). Dev Comp Immunol 70: 94-105.

55. Yasuike M, Boer J, Schalburg KR, et al. (2010): Evolution of duplicated IgH loci in Atlantic salmon, Salmo salar. BMC Genomics 11: 486.

56. Bao Y, Wang T, Guo Y, et al. (2010): The immunoglobulin gene loci in the teleost Gasterosteus aculeatus. Fish Shellfish Immunol 28: 40-48.
57. Ryo S, Wijdeven RHM, Tyagi A, et al. (2010): Common carp have two subclasses of bonyfish specific antibody IgZ showing differential expression in response to infection. Dev Comp Immunol 34: 1183-1190.

58. Xu Z, Parra D, Gomez D, et al. (2013): Teleost skin, an ancient mucosal surface that elicits gut-like immune responses. Proc Natl Acad Sci U S A 110: 13097-13102.

59. Zhang YA, Salinas I, Li J, et al. (2010): IgT, a primitive immunoglobulin class specialized in mucosal immunity. Nat Immunol 11: 827-835.

60. Savan R, Aman A, Nakao M, et al. (2005): Discovery of a novel immunoglobulin heavy chain gene chimera from common carp (Cyprinus carpio L.). Immunogenetics 57: 458-463. 